\title{
Neuropeptides encoded by the genomes of the Akoya pearl oyster Pinctata fucata and Pacific oyster Crassostrea gigas: a bioinformatic and peptidomic survey
}

Michael J Stewart ${ }^{1 \dagger}$, Pascal Favrel ${ }^{2,3+}$, Bronwyn A Rotgans ${ }^{1}$, Tianfang Wang ${ }^{1}$, Min Zhao ${ }^{1}$, Manzar Sohail ${ }^{1}$, Wayne A O'Connor ${ }^{4}$, Abigail Elizur ${ }^{1}$, Joel Henry ${ }^{2}$ and Scott F Cummins ${ }^{1 *}$

\begin{abstract}
Background: Oysters impart significant socio-ecological benefits from primary production of food supply, to estuarine ecosystems via reduction of water column nutrients, plankton and seston biomass. Little though is known at the molecular level of what genes are responsible for how oysters reproduce, filter nutrients, survive stressful physiological events and form reef communities. Neuropeptides represent a diverse class of chemical messengers, instrumental in orchestrating these complex physiological events in other species.

Results: By a combination of in silico data mining and peptide analysis of ganglia, 74 putative neuropeptide genes were identified from genome and transcriptome databases of the Akoya pearl oyster, Pinctata fucata and the Pacific oyster, Crassostrea gigas, encoding precursors for over 300 predicted bioactive peptide products, including three newly identified neuropeptide precursors PFGx8amide, Rxlamide and Wx3Yamide. Our findings also include a gene for the gonadotropin-releasing hormone $(\mathrm{GnRH})$ and two egg-laying hormones (ELH) which were identified from both oysters. Multiple sequence alignments and phylogenetic analysis supports similar global organization of these mature peptides. Computer-based peptide modeling of the molecular tertiary structures of ELH highlights the structural homologies within ELH family, which may facilitate ELH activity leading to the release of gametes.

Conclusion: Our analysis demonstrates that oysters possess conserved molluscan neuropeptide domains and overall precursor organization whilst highlighting many previously unrecognized bivalve idiosyncrasies. This genomic analysis provides a solid foundation from which further studies aimed at the functional characterization of these molluscan neuropeptides can be conducted to further stimulate advances in understanding the ecology and cultivation of oysters.
\end{abstract}

Keywords: Pinctada fucata, Crassostrea gigas, Molluscs, Circular dichroism, Egg-laying hormone, Feed circuit activating peptide, Gonadotropin-releasing hormone, High-performance liquid chromatography, Mass spectrometry, Neuropeptides

\footnotetext{
* Correspondence: scummins@usc.edu.au

${ }^{\dagger}$ Equal contributors

${ }^{1}$ School of Science and Education, Genecology Research Center, University of

the Sunshine Coast, Maroochydore DC, Queensland 4558, Australia

Full list of author information is available at the end of the article
} 


\section{Background}

Neuropeptides encompass a diverse class of cell signaling molecules that are produced and released from neurons through a regulated secretory pathway [1]. They may function as hormones, transmitters and modulators; as modulators of neuronal activity, neuropeptides contribute to the generation of different outputs from the same neuronal circuit in a context-dependent manner [2], or organize complex motor functions [3]. Neuropeptides that act as hormones are released into the haemolymph via a network of neurohemal organs, upon which they regulate various states of physiology, including growth, metabolism, and reproduction [4].

In general, neuropeptides are generated from an immature precursor that contain an N-terminal signal sequence and single or multiple copies of bioactive peptide [5]. Mature bioactive peptides are often short with low in molecular weights $(<10 \mathrm{kDa})$, the shortest and smallest being dipeptides [6,7]. Within the secretory apparatus, proteases cleave the precursor at mono- or dibasic cleavage sites [8], after which mature peptides are often further modified through post-translational modifications [9]. Conventional methods of neuropeptide characterization have involved their purification directly from neural-associated tissues in conjunction with the analysis of corresponding gene expression. Identification of cross-species neuropeptide conservation has typically relied on the use of antibody probes that bind to homologs. However, given the relative ease and affordability of genomics and mass spectrometry, the near full neuropeptide repertoire of several species has been revealed [10], even within non-model animal species [11].

One mollusc in which genomics has helped to reveal the extent of the neuropeptidome is the owl limpet, Lottia gigantea. Lottia is a marine gastropod that has emerged as a molluscan genome model following the recent sequencing of its relatively small genome. Data mining of the $L$. gigantea genome has revealed around 59 genes that encode for putative neuropeptides [12], most of which had been previously characterized or identified through functional testing or descriptively identified (i.e. immunohistochemistry) in other molluscs, insects or annelids. Examples of these include the tetrapeptides Ala-ProGly-Trp- $\mathrm{NH}_{2}$ (APGWamide) and Phe-Met-Arg-Phe$\mathrm{NH}_{2}$ (FMRFamide), as well as the egg laying hormone $(\mathrm{ELH})$ and gonadotropin-releasing hormone $(\mathrm{GnRH})$ [12]. While most genes encoding neuropeptides have not been identified in molluscs, some that have, do share distinct homology with Drosophila, such as the putative proctolin homolog PKYMDT and allatostatin $\mathrm{C}$, which are believed to be derived from neuropeptides with an early origin from either eumetazoan or bilaterian ancestors $[2,10]$.

Most research in oysters has been devoted to understanding their widespread ecological impacts, nutrient processing, nutrition, larval settlement, and environmental factors that modulate spawning frequency and distribution. However, little is known of the metabolic neuropeptides that regulate these processes. Insight into this area has the potential to be either exploited for advances in oyster culture, or for controlling and understanding their natural biological processes which contribute to their invasiveness. Recently, genome sequence assemblies and annotations became available for Pinctata fucata and Crassostrea gigas, providing an excellent opportunity to characterize the repertoire of oyster neuropeptides [13,14].

The Akoya pearl oyster Pinctata fucata, are wide spread and can form dense populations, but are cultured primarily for their ability to produce pearls [15]. The $P$. fucata draft genome version 1.1 (approximately 40x coverage) became available in 2012 predicting 23,257 complete gene models and includes genes associated with shell biomineralization [13], as well as reproduction-related genes involved in the process of germ cell migration; vasa, nanos, oocyte maturation, and spawning. This includes 5-hydroxytryptamine, vitellogenin and estrogen receptors [16]. On the other hand in the same year analysis of the highly polymorphic C. gigas genome and transcriptomes revealed an extensive set of genes that provides a rare glimpse of how C. gigas respond to environmental stress, and adapt to near environments, as well as giving insight perspective into the molecular mechanism of shell formation, development and reproduction [14].

In this study, we interrogated the genomes and transcriptomes of $P$. fucata and C. gigas to identify neuropeptide genes. To help support gene predictions, we performed comparative analysis and peptidomic investigation of C. gigas ganglia. Among those neuropeptides identified are those known to be involved in molluscan reproduction (e.g. APGWamide, egg-laying hormone and gonadotropin-releasing hormone) and growth (e.g. FMRFamide). This study provides a foundation for the experimental analysis of neuropeptides in oysters, which can be used to increase focus on the loss of associated ecosystem and food supply services that oysters contribute to the environment and human well-being.

\section{Results and discussion}

We have identified genes encoding putative full-length or partial-length neuropeptide precursors from the $P$. fucata and C. gigas genome, and transcriptome databases for C. gigas (Figure 1 and Additional file 1). Numerous peptides are released from these precursors, some of which were confirmed from C. gigas neural tissue by liquid chromatography-tandem mass spectrometry (LC-MS/MS) analysis (Additional files 2, 3 and 4). For some of the neuropeptides, defined roles in reproduction and growth have been established and will 


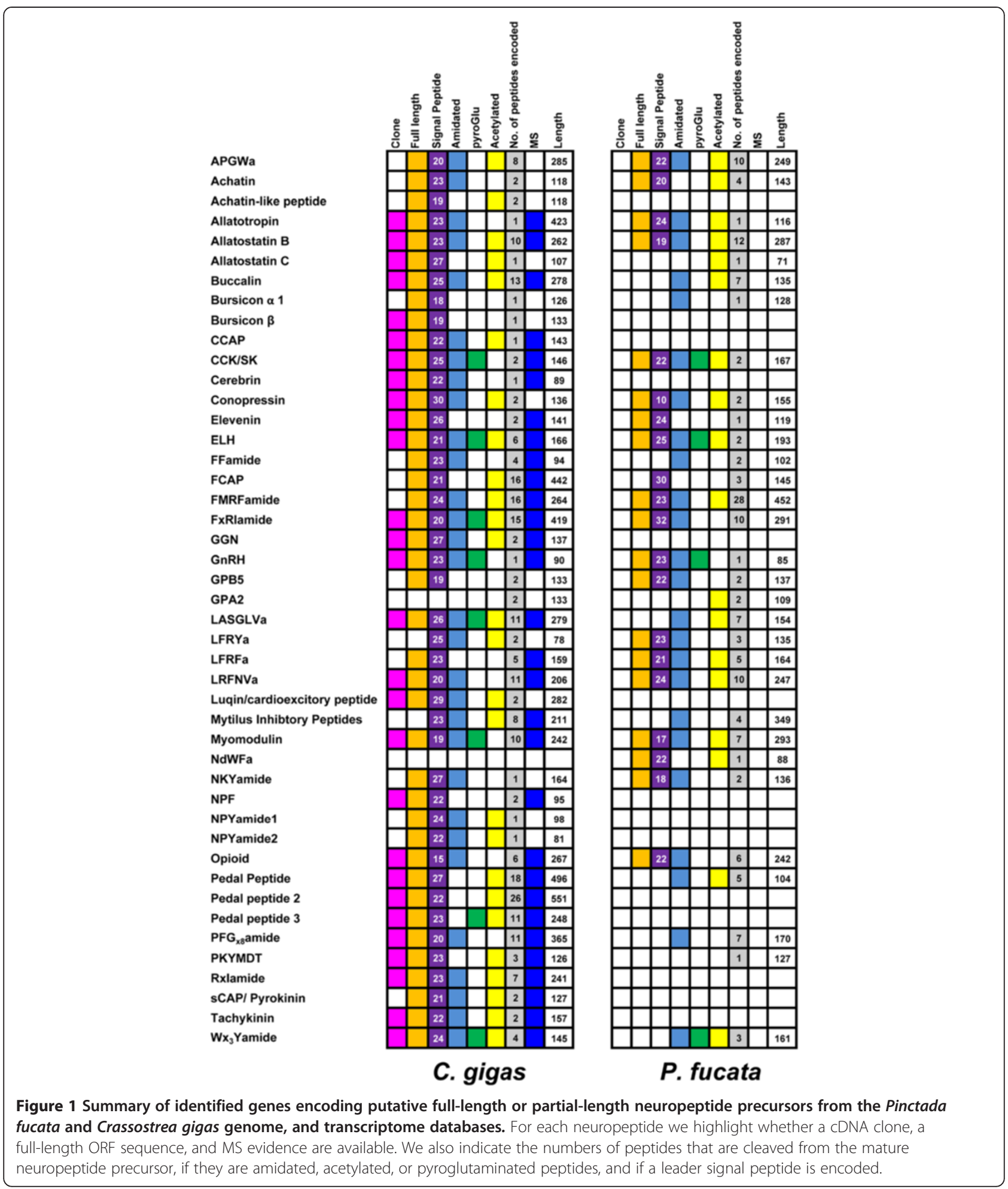

be discussed in the context of the newly identified oyster sequences. Database accession numbers for sequences used in this study can be found in Additional files 2 and 5.

\section{APGWamide and FMRFamide}

Molluscan APGWamide and FMRFamide precursors share a similar configuration, that is, they contain numerous tetrapeptide repeats that can vary slightly besides the 
presence of a C-terminal dipeptide amidation (i.e. GWa and RFa). APGWa precursors previously described in the aquatic gastropods Aplysia californica [17], Lymnaea stagnalis [18], Lottia gigantea [12] contain primarily APGWa whose putative function has been reviewed by Koene 2010 [19]. The related GWa, TPGWa, KPGWa and RPGWa peptides have been identified in the cuttlefish Sepia officinalis [20,21] and the blue mussel Mytilus edulis [22,23], through HPLC and LC-ESI-MS/MS. Those studies suggest that these related variants might play a significant role in cephalopod and bivalve reproduction. We found that the Pf-APGW precursor is predicted to be cleaved at several dibasic sites, to release six RPGWa peptides (513.3 Da), three KPGWa peptides $(485.3 \mathrm{Da})$ and one APGWa (470.24 Da) (Figure 2A and Additional file 2). Unfortunately no KPGW or RPGW was identified in MS analysis.
The Cg-APGW precursor encodes fewer repeats yet has a longer precursor (285 residues). When compared to other APGWa precursors of mollusc, it appears that gastropods more frequently contain the APGWa peptide rather than the TPGWa, RPGWa or KPGWa of bivalves (P. fucata, $C$. gigas and M. edulis [22]). The notable substitution of alanine (A) with threonine $(\mathrm{T})$, arginine $(\mathrm{R})$ or lysine $(\mathrm{K})$ at position 1 in bivalves creates a peptide that is less hydrophobic [22], perhaps imparting a necessary change for it to be bioactive in oysters, mussels and cephalopods.

RFamides, which feature a C-terminal sequence - RFa, constitute one of the largest families of neuropeptides and include the FMRFa and FxRIamide [24-27]. The FMRFa peptides have been described from numerous molluscs, where they have been shown to have a diversity of roles as neurotransmitters, neuromodulators, and

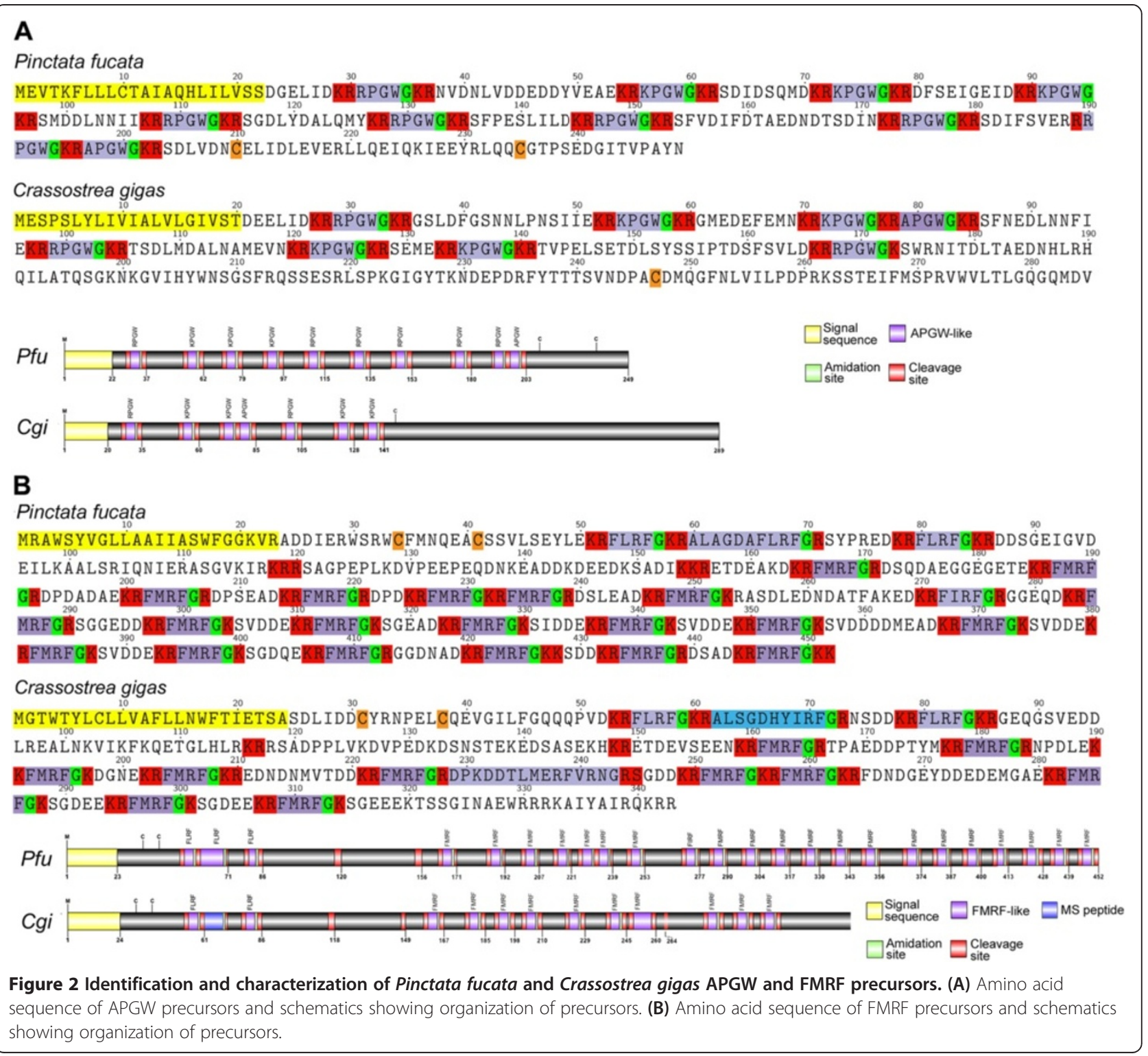


neurohormones [28]. The Pf-FMRF gene encodes a precursor of 452 residues, including a 23-residue signal peptide, two FLRFa (580.36 Da), twenty FMRFa (598.31 Da), a FIRFa (580.36 Da) and a hydrophobic ALAGDAFLRFa (1078.6 Da) (Figure 2B and Additional file 2). The CgFMRF precursor also contains two FLRFa, although fewer FMRFa (ten) and the decapeptide, ALSGDHYIRFa was subsequently identified by mass spectrometry from the visceral ganglia. Interestingly, FMRF precursors exhibit high retention in conservation of the FMRFa with other molluscs but not FLRFa. This may be due to an evolutionary split from a common ancestral precursor [29] and could be unique to bivalves.

Quite similar to the FMRFa is FxRIamide (Additional file 1). This peptide is commonly found in lophotochozoans $[30,31]$, and has been also called S-Iamide peptide due to its common structure, -SSFVRIamide after it was first reported (LSSFVRIamide) in the prosobranch mollusc Fusinus ferrugineus [32]. Since then, partial precursors and fragments of heptapeptides all with the structural amino acid arrangement of XSSFxRI have been reported in the annelids, Platynereis demurilii, Pomatoceros lamarckii, Capitella capitata, and molluscs Aplysia and Lottia [31]. Here we now also report the identification of full-length precursors of FxRIamide for both oysters, $P$. fucata and $C$. gigas. The Pf-FxRIa gene encodes leader 22 residue signal peptide as well as 11 unique heptapeptides all with the structural amino acid arrangement of xSSFxRI. Of note, in addition there are two longer peptides IPSSAFMRIa and PSRLGQSSFVRIa. In C. gigas, the Cg-FxRIa gene has in addition to leader signal peptide, 14 unique FxRI peptides. The unique feature of these FxRI homologs is that they generally are missing the upstream amino acid sequence SS. Only one peptide, verified by MS analysis conformed to the XSSFxRI convention, IQQSSFIRI. Overall the significance of these peptides in molluscs and in annelids is relatively unknown. However, it has been suggested that the peptides may be involved in the regulation of gut motility of the animal [30].

\section{Gonadotropin-Releasing Hormone and Egg-Laying Hormone}

In oysters, synchronized gonad maturation and spawning is thought to occur via environmental cues, including tides and pheromonal cues released by conspecifics that initiate endogenous cues [33]. The GnRH and ELH peptides have been most well studied in relation to endogenous reproduction hormones. Although much is known about the role of $\mathrm{GnRH}$ in vertebrate reproduction [34], we are only just beginning to explore its function in molluscs. In molluscs, a GnRH was first identified in the Octopus vulgaris [35]. Later identified also in the sea slug Aplysia californica, it was determined that although administration of synthetic GnRH could stimulate behaviours such as inhibition of feeding, no effect on ovotestis, reproductive tract, egg-laying or penile eversion was observed [36]. However, in the scallop Patinopecten yessoensis, mammalian GnRH can stimulate spermatogonial proliferation [37]. Two GnRH-related peptides were later found by mass spectrometry of the C. gigas visceral ganglia, and gene expression analysis demonstrated a correlation with reproduction and nutritional status [38]. The Pf-GnRH and gene identified in the present study encodes for a precursor of 59 amino acids, and includes the conserved 11 residue $\mathrm{GnRH}$-like peptide and $\mathrm{C}$-terminal GnRHassociated peptide (GAP) (Figure 3A). The GnRH-like peptide of $P$. fucata and the previously reported $C$. gigas GnRH differ at only residue 10 (ie. His for P. fucata and Gln for C. gigas). The general organization of the $\mathrm{GnRH}$ precursor has been conserved throughout evolution and with the exclusion of chicken, tree shrew, fish and primates, most species of vertebrate possess one or two cysteines within the GAP (Figure 3B). In comparison with other $\mathrm{GnRH}$ peptides, most similarity is found within the $\mathrm{GnRH}$ peptide (Figure 3C), and based on phylogenetic analysis of GnRH precursors (Figure 3D) the Pf-GnRH clusters most closely with the cephalopod Octopus vulgaris, rather than the bivalves $C$. gigas and Patinopectin yessoensis.

The egg-laying hormone has received significant attention due to the nature of its function in eliciting egg laying in A. californica, from which it was first discovered [39]. Its gene structure is typical of many molluscan neuropeptides in that it is derived from a precursor that gets processed by processing enzymes, such as prohormone convertase [40]. The Pf-ELH gene (pfu_aug1.0_2069.1_29971) primary sequence has been described previously [16] where it encodes a 158 amino acid preprohormone consisting of a 26-residue signal peptide and two ELH-like domains (Figure 4A). Herein, we show that the Pf-ELH1 consists of a 42 amino acid basic peptide (5016.9 Da) and PfELH2 consists of a 38 residue ELH-like acidic peptide (4189.11 Da), both of which are predicted to be cleaved and amidated from a common precursor at $S_{26}$. The Cg-ELH was first described by Veenstra [12], revealing a precursor slightly larger (166 amino acids) than the Pf-ELH, but similarly contains two ELH-like peptides (Pf-ELH1 has 40 residues and Pf-ELH2 has 38 residues).

Schematic representations show that only oysters contain ELH peptides on the same precursor (Figure 4B) and only the Aplysia and Lymnaea ELH precursors have other known bioactive peptides [such as bag cell peptides (BCPs), caudodorsal cell peptides (CDCPs)]. Multiple sequence comparison and phylogenetic analysis of known ELH peptides shows that oyster ELH1 is most closely related to oyster ELH2 peptides (Figure 4C,D). Most conservation of ELH between molluscan species is located at the $\mathrm{N}$ - and $\mathrm{C}$-termini, probably as these are critical for 


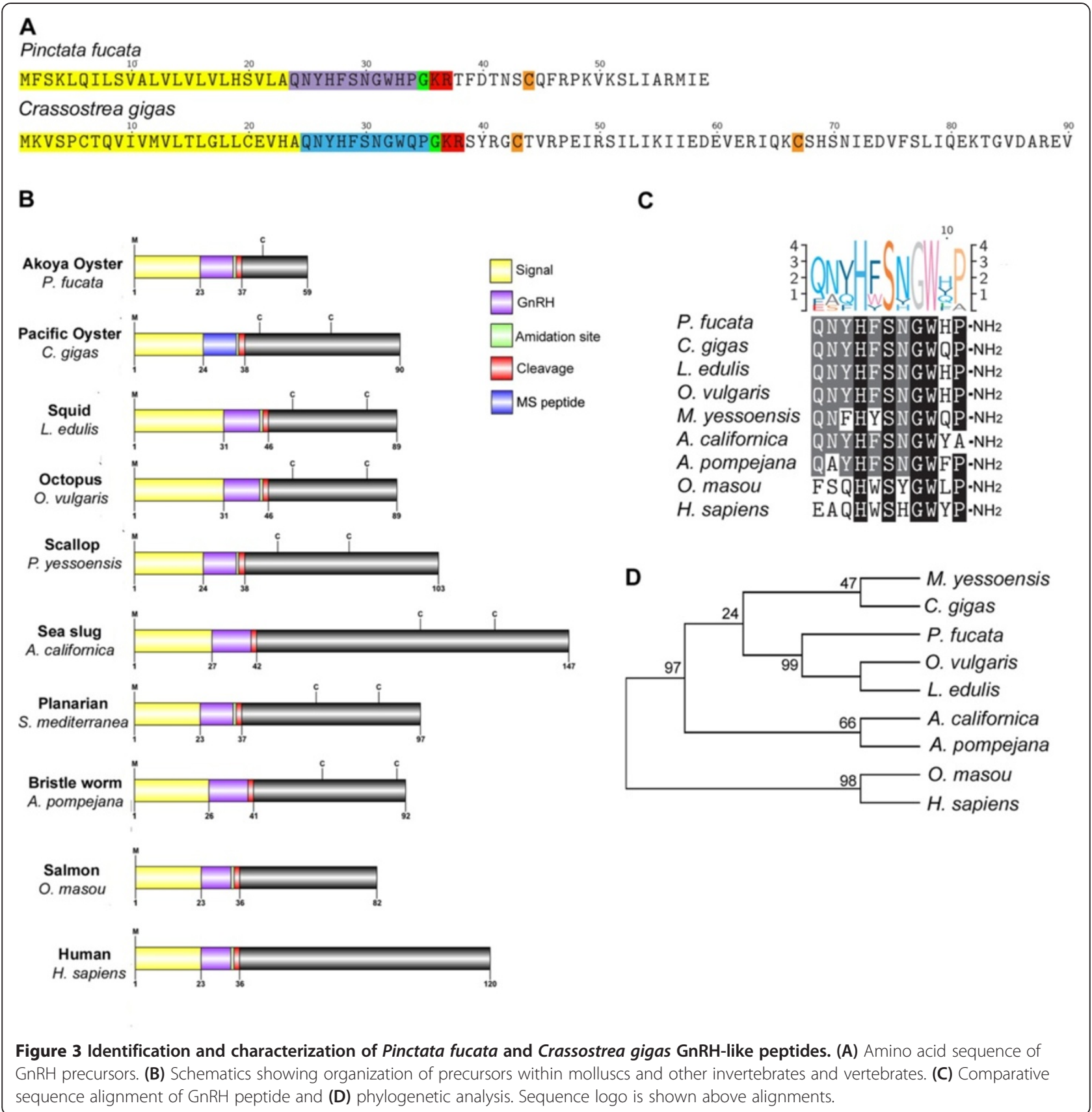

receptor interaction. In support of this, previous structure and activity studies have used synthetic ELH analog variants to investigate egg-laying induction [39]. In that study, removal of the N-terminal amino acid or extension of the $\mathrm{C}$-terminus by one residue $\left(\mathrm{Gly}_{37}\right)$ caused loss of egg-laying activity. Further analysis revealed that ELH is more similar within the Aplysia family; where $A$. dactylomela ELH differs from $A$. californica (and $A$. brasiliana) ELH at only four positions [41]. We further compared oyster ELH to the recently identified members of the corticotropin-releasing hormone $(\mathrm{CRH})$ and diuretic hormone 44 [DH44] neuropeptide families reported in other species (Figure 4C). CRH/DH44 have been implicated as being related to mollusc ELH [10], demonstrating sequence similarity within the mature peptides. For example, Aplysia ELH compared to DH44, reveals several conserved amino acid positions, including the Platynereis DH44, which is highly repetitive (13 and 16 copies) compared to mollusc ELH or insect DH44 counterparts [31]. Human CRH, with 4 identicalsemi conserved residues, had the least conservation compared to mollusc ELH, and formed its own sub- 
A

ELH1

Pinctata fucata

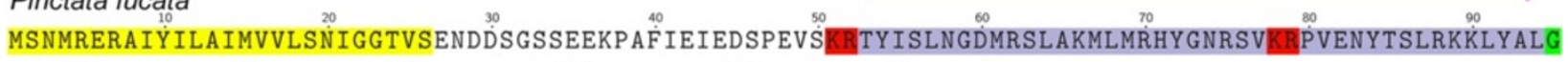

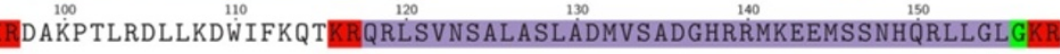

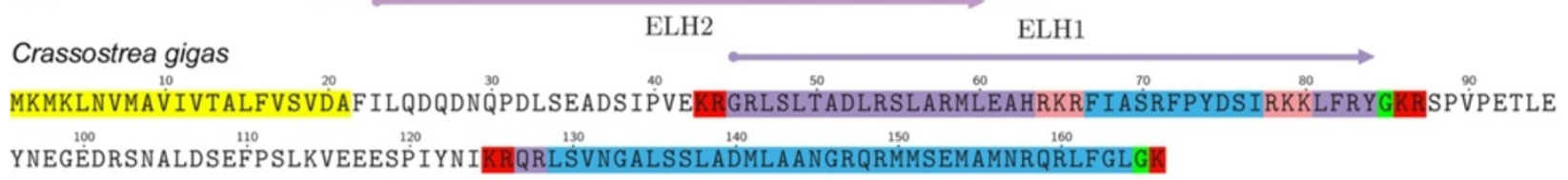

B
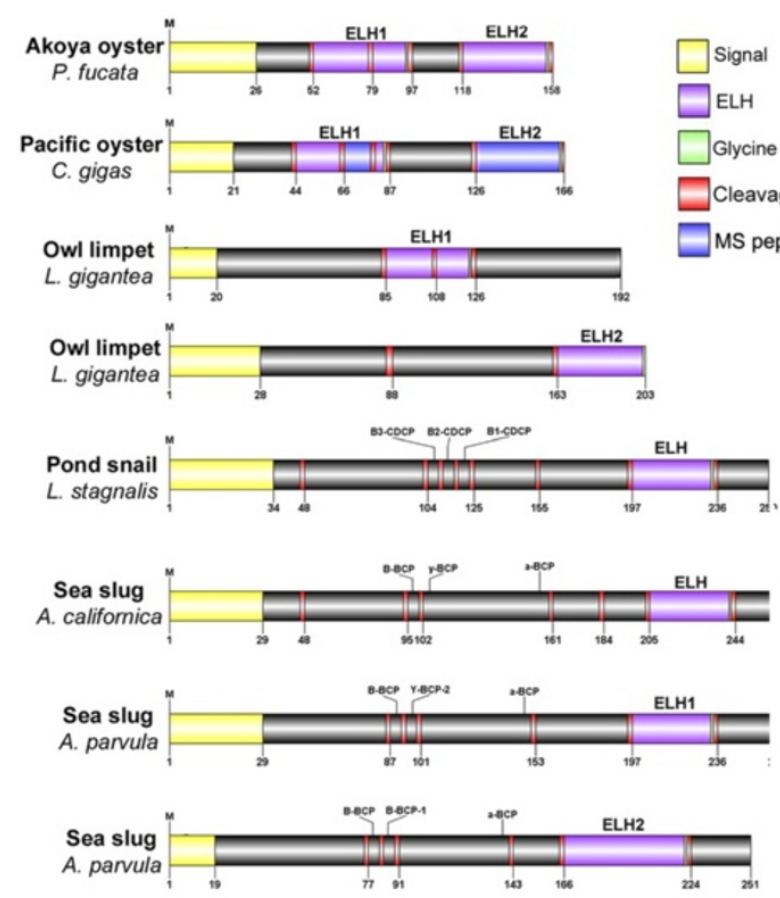

E
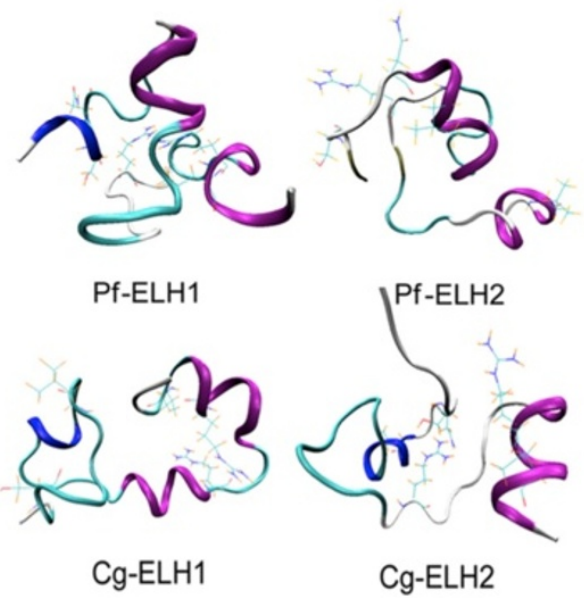

ELH2

C

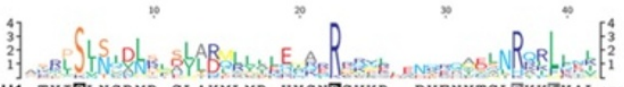
P. fucata ELH1. TYISLNGDMR. SLAKMLMR, HYGMRSVRR . PVENYTSLRKKEYAL NH2

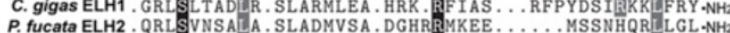

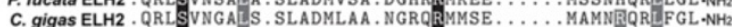
gigantea ELH2 AGRLSING ALS. SLADLLVS, ENQRRRDRLE...... SMEL. RQRILQYL.NHE L. gigantea ELH1. SRLSINQELK. SLANLLVLRENKRREAQK ....... TKL. ASKLLSI NH

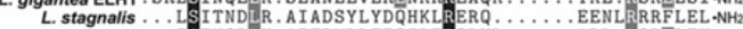
A. californica .... I I INQDLK. AI TDMLLTEQ IRERQRYL ........ADL. RQRELEK NH A. dactylomela $\ldots$. SINQDLK. AITDMLLEEKIRER QRYL........ADL. RQRLLQK NH2 A. parvula AK. IS INQDLLK. AIADMLIVEQKQEEREKL........ADL. RQRLLNK NH T. A A. mellifera DH44 - RTGLST WSMDLRQR A. D. melanogaster DH44. TKP SLSI VNPLDVLRQRI IL MMA. RRQMR. ENTROVEL NKALLRET NHE

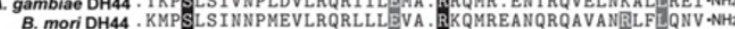
demurilii DH44-2 .... KLSVWNG . . LS . . ALANSM . KDKEL ... EDG IQTSHAQL FRM NH2

$H$ sapiens UCN-1. DMPSLSIDLTFHLLRT . LLELA. RTQSQ . . . RERAEQNRIFDSV NH H sapiens CRH SEEP ISLDLTFHLLRE.. VLEMA . BAEQL..... AQQAHSNDKLMEI I NH

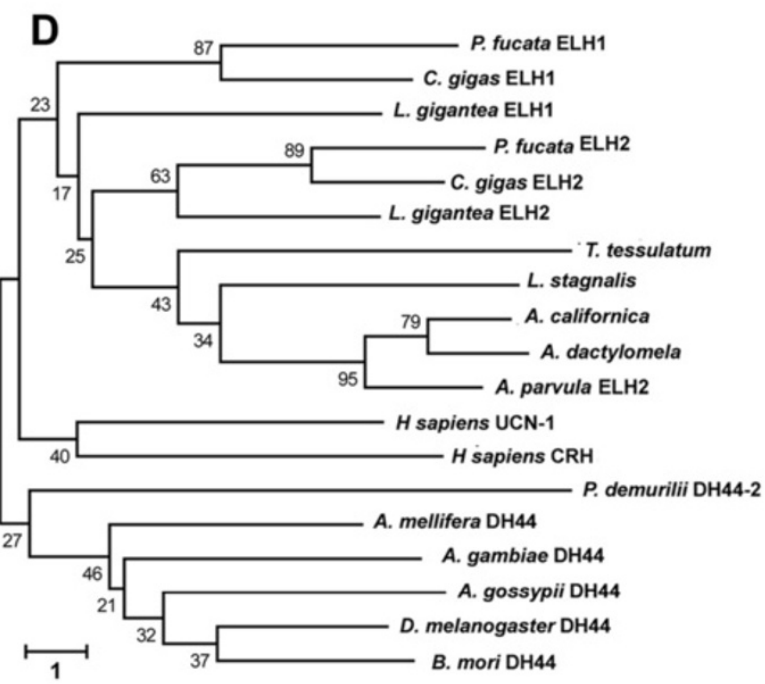

$\mathbf{F}$

LSVNGALSSLADMLAANGRQRMMSEMAMNRQRLFGLa

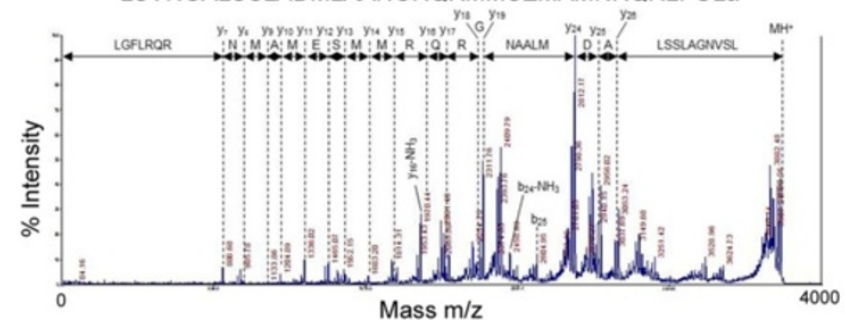

Figure 4 (See legend on next page.) 
(See figure on previous page.)

Figure 4 Identification and characterization of $P$. fucata and $C$. gigas ELH-like peptides. (A) Amino acid sequences of $P$. fucata and C.gigas ELH precursors. (B) Schematics showing ELH precursors identified in molluscs. (C) Comparative sequence alignment and (D) Phylogenetic analysis of bioactive ELH/DH44/CRH region between species. Sequence logo is shown above alignments. (E) Protein models of oyster ELH1 and ELH2 assembled from molecular dynamics simulation. Secondary structures: blue, helix; purple, alpha-helix; cyan, turn; white, random coil; dark yellow, isolated beta bridge. (F) Off-line nLC-MALDI tandem MS analysis of Crassotrea gigas cerebral ganglia. MS/MS spectrum of the egg-laying hormone Cg-ELH2 m/z 3939. Immonium, a-, b- and y-ions detected are marked.

branch (Figure 4D). Nevertheless, conservation of these neuropeptides in lophotochozoans further confirms the coevolution of these peptides [10].

No ELH peptide structure model predictions or crystal structures have been reported to date. To help further studies to what may activate an ELH receptor, we undertook predictive structural analysis. Oyster ELH structure molecular models for Pf-ELH1, Pf-ELH2, Cg-ELH1 and Cg-ELH2 predict that ELH1 contains a mixture of helix, $\alpha$-helix, turn, beta-strand and random coil (Figure 4E). It appears that the highly conserved $\mathrm{S}_{4}$ and $\mathrm{N}_{6}$ regions exhibit more of a random-unordered structural character, while $\mathrm{L}_{9}$ is located within a helix region (i.e., $\alpha$-helix in PfELH2, 3-10 helix in Cg-ELH1 and Cg-ELH2, respectively). For Cg-ELH2, $\mathrm{R}_{27}$ is located within random coil regions, and is adjacent to an $\alpha$-helix region in Cg-ELH1. Meanwhile, in Pf-ELH1 both $\mathrm{R}_{36}$ to $\mathrm{L}_{39}$ are within a C-terminal $\alpha$-helix, which is the same in all ELH models excluding PfELH2. The potential energy as a function of time during this simulation and the backbone root-mean square distance (RMSD) relative to this structure during the course of the same simulation is shown in Additional file 6 (A-D). The representative structure of Pf-ELH1 and Cg-ELH1 occurred at $197.540 \mathrm{~ns}$ and $77.028 \mathrm{~ns}$ into the MD simulation, respectively. The representative structure of Pf-ELH2 and Cg-ELH2 resolved at 239.778 ns and 100.761 ns into the MD simulation, respectively. Subsequent analysis of the secondary structure of Pf-ELH1 based on circular dichroism (CD) spectroscopy found that the peptide was predominantly beta-strand (36\%; peaking at $180-190$, and 200-210 $\mathrm{nm}$ respectively) (Additional file 6). In addition, the spectrum (particularly the trough from $210-230 \mathrm{~nm}$ ) indicates a consistent $\alpha$-helical structure with minor notable random coils throughout (17\%; trough 190-200 nm).

Our LC-MS/MS analysis of C. gigas neural tissue identified an internal region of Pf-ELH1 (FIASRFPYDSI) and Pf-ELH2 as well as a 36 amino acid form of Cg-ELH2 of $\mathrm{m} / \mathrm{z} 3939$ (Figure 4F). Whether this form is the biologically active form or just a slightly truncated form remains to be investigated. MS did not detect the 38-residue ELH, probably because its mass exceeds M/Z 4000, which in our analysis was the upper limit of detection.

\section{Other neuropeptides of interest}

Full-length neuropeptide precursors were identified in $P$. fucata and C. gigas for achatin, allatotropin, cholecystokinin
(CCK)/sulfakinin (SK)-like, conopressin, elevenin, NKY, NPF/Y and LFRFa (Figure 5). Multiple sequence alignment between the oyster putative neuropeptide precursors with previously identified homolog sequences in mollusc confirms high identity within the bioactive peptide sequences and variability outside these regions. Bioactivity of the intervening sequences has not previously been described.

\section{Achatin}

The neuropeptide, achatin, was first identified in giant African snail ganglia [42] and within that animal it has both suppressing and enhancing actions on the effects of various neurotransmitters [43]. Similar to other known molluscan achatin precursors, those of Pf-achatin and Cg-achatin may be processed to release GFWD and GFGD acidic peptides.

\section{Allatotropin}

The allatotropin peptide stimulates synthesis of juvenile hormones in insects [44], where it has been most well studied. Pf-allatotropin and Cg-allatotropin encode for allatotropin precursors that can be cleaved to produce a 14 amino acid allatotropin peptide, GFRQSIIDRMGHGFa for P. fucata and GFRQSIVDRMGHGFa for C. gigas which was confirmed by mass spectroscopy [MS] analysis. While allatotropin is highly conserved between these oysters, there is only limited similarity with other known allatotropins besides the $\mathrm{N}$ - and $\mathrm{C}$-terminal regions.

\section{CCK/SK}

The molluscan oyster homolog genes for CCK/SK encode for peptides of Pf-p-QGVWDFDYGLGGGRFa (1655.79 Da) and Cg-p-QGAWDYDYGLGGGRFamide $(1643.74 \mathrm{Da})$ that share some similarity with sulfakinin and gastrin. An additional co-peptide of Pf-SFGDYSLGG GRFamide and Cg-FDYNFGGGRWamide is also present directly following the CCK/SK peptide. Both C. gigas peptides were confirmed by MS analysis (Additional file 3). CCK is structurally and functionally related to the gastrin hormone, both of which regulate digestion and feeding in invertebrates [45].

\section{Conopressin}

The Pf-conopressin and Cg-conopressin, encoded a single vasopressin-related conopressin precursor. Immediately following the signal peptide cleavage site is the highly 


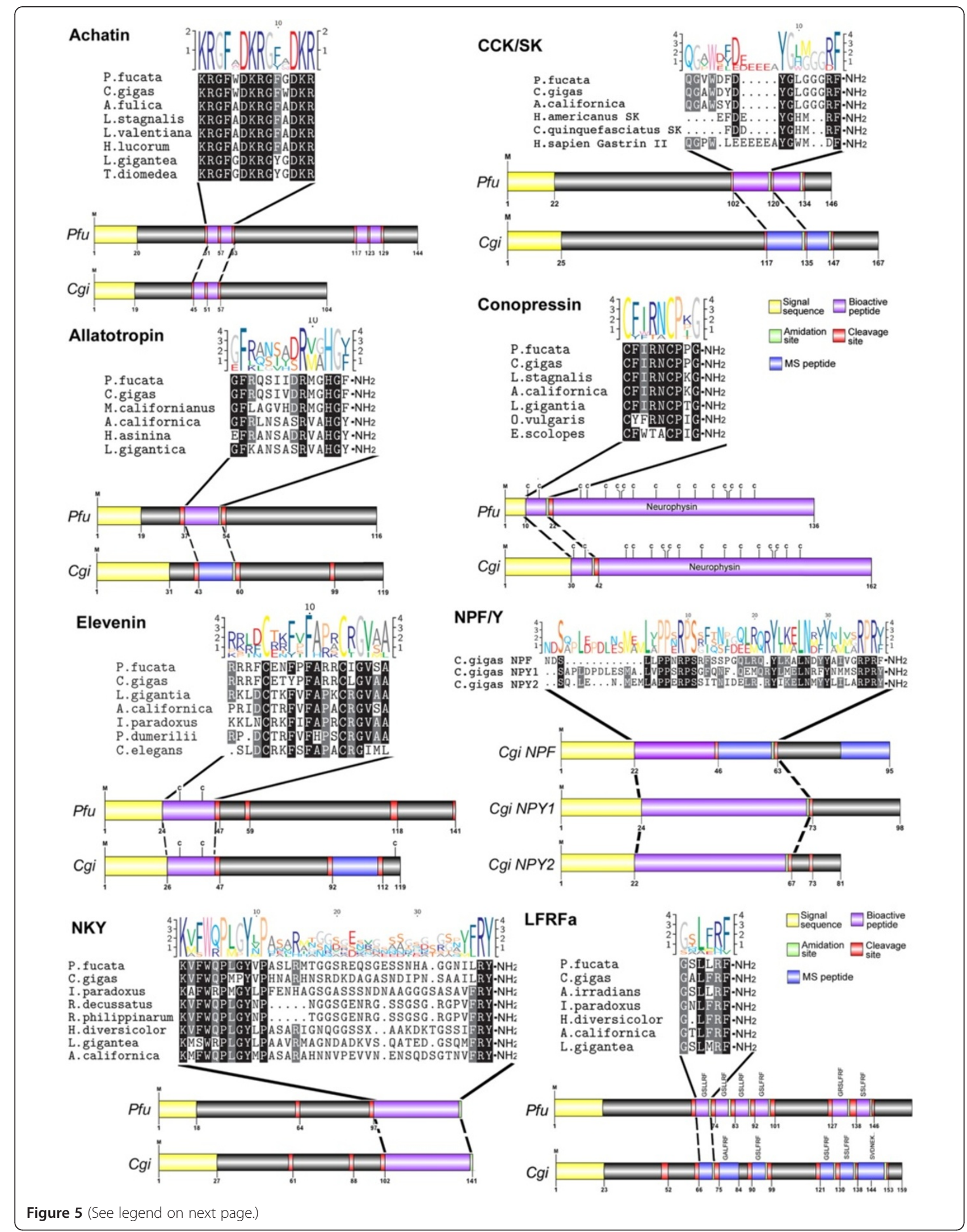


(See figure on previous page.)

Figure 5 Identification of Pinctata fucata and Crassostrea gigas neuropeptides. Comparative sequence alignment and schematic representation of precursors for $P$. fucata (Pfu) and C. gigas (Cgi). Full-length precursor sequences were identified in both for achatin, allatotropin, CCK/SK and conopressin, elevenin, NKY, NPF/Y and LFRFa, showing high amino acid identity within bioactive peptides. A sequence logo is shown above alignments, where the height of each letter is proportional to the observed frequency of the corresponding amino acid in the alignment column.

conserved $\mathrm{N}$-terminal conopressin peptide, predicted to be CFIRNCPPG- $\mathrm{NH}_{2}$, while the adjoining C-terminal neurophysin peptide contains 14 cysteine residues and is followed by an uncleaved copeptin-homologous domain. Bivalve conopressin differs from gastropod conopressin at the most polymorphic position in the peptide: position 8 . In the genetically highly polymorphic $C$. gigas, nucleotide variability even occurs at this position $(\mathrm{A} / \mathrm{C})$ changing $\mathrm{Q}$ to P. This polymorphic change could be due to a SNP within a population. The conjoined neurophysin-like peptide, although quite divergent, shows spatial conservation of cysteine residues throughout all molluscs as well as in vertebrates and even the NG peptide-associated neurophysins first identified in the sea urchin, S. purpuratus [46]. In Lymnaea, conopressin controls sexual behavior [47].

\section{Elevenin}

Pf-elevenin and Cg-elevenin genes encode an active elevenin peptide that is cleaved from the precursor, KPRRRFCENFPFARRCIGVSA and RRRFGETYPFARRC LGVAA, respectively. LC-MS/MS analysis of C. gigas neural tissue identified the SPVSLLEQILNNRRRFGL peptide (Additional file 2), indicating that this is probably a bioactive peptide released from the precursor. Eleveninlike precursors have been described in Lottia gigantea [12] and Aplysia [48], while a similar precursor from the pygmy squid Idiosepius and nematode Caenhorabditis elegans are present within the NCBI Genbank database. Comparison of the oyster elevenin precursors with other molluscs and worms shows little overall conservation, even within the elevenin mature peptide, however, there is conservation of cysteine residues at positions 5 and 14 .

\section{NKY, NPY/F family}

Full-length neuropeptide precursors were identified in $P$. fucata and C. gigas for NKY and NPY/F. Multiple sequence alignment between the oyster putative neuropeptide precursors with previously identified homolog sequences in mollusc confirms high identity within the bioactive peptide sequences and variability outside these regions. The oyster neuropeptide, neuropeptide KY (NKY) was predicted from precursor cleavage based upon the presence of an $\mathrm{N}$-terminal lysine residue and $\mathrm{C}$-terminal tyrosine residue [12]. The Pf-NKY and Cg-NKY precursors are likely cleaved to release a bioactive peptide of 38 residues with a molecular weight of $4150.64 \mathrm{Da}$ and 4337.84 Da, respectively. Conservation with other NKY exists primarily within the $\mathrm{N}$ - and C-terminal regions, while there is limited amino acid identity in the middle region of the precursor. Oyster genome encodes at least three NPY/Fs. Though C-terminal RxRFamide peptides were initially considered as the protostome forms, oysters actually express both a NPF and two NPY peptides. Organization of the oyster genes is similar to those reported in different animal taxa with exons coding for similar domains of the precursor and an intron splicing within the codon of the arginine residue of the C-terminal RF/ Yamide sequence $[49,50]$. This argues for an early origin of the NPY/F family. In contrast to annelids, oyster genes are however not in tandem position as they are situated on different scaffolds.

\section{LFRFamide}

The oyster LFRFamide ( $P f-L F R F a$ and $C g$-LFRFa) gene encodes for multiple basic GXLL/FRFa peptides while the LFRYamide ( $P f-L F Y a$ and $C g-L F Y a$ ) gene encodes single variant FRF/FRW peptides along with a well conserved associated double disulphide-bridged peptide. While there was no confirmation of C. gigas LFRYa peptides by LC-MS/MS, several -LFRFa peptides were. Functionally LFRFa peptides have known to inhibit electrical activity of neuroendocrine cells that control either growth and metabolism or reproduction in L. stagnalis [25]. However, in the cephalopod Sepia officinalis, LFRFa activity is predominantly targeted to the rectum, where it increases the frequency, tonus and amplitude of rectal contractions [51]. More recently in C. gigas where the receptor for this family of peptides had been characterized it has been suggested that signalling of LFRFamide peptides through its specific receptor might play a role in the coordination of nutrition, energy storage and metabolism [52]. In this paper we thus showed the molecular existence of these different peptides by MS/MS in $C$ gigas and confirm further via PSI-BLAST molecular analysis that LFRFa would represent functional orthologs of short neuropeptide F from insects [52].

Full and partial-length P. fucata and C. gigas genes were also identified that encoded peptides with identity to allatostatin C (SHIRCLVNVIACY), buccalins (11 variants), CCAP (VFCNGFFGCSNamide, and LFCNTGGCFamide [although these were not verified by MS analysis]) cerebrin/ PDF-like (NLGTVDSLYNLPDLLYRamide), FFamide/SIFlike peptides (GMNPNMNSLFFamide) similar in structure to the FFamides found in Lymnaea [53], FCAP, 
GGNamide (SKCKGPWANHMCFGGNamide), LASGLVamide (MMDPLASGLVa), LFRYa (SIKIPFRFa), luqin (APQWRPQGRFamide and VCVESNVPGLFKCY), two myomodulin variants (GMPMLRLamide, PFKMLRLamide GGLSMLRL, GLQMLRLamide, and AMPMLRLamide) and (xG/KFFRIamide), Pedal peptide, PKYMDT, sCAP (small Cardio Active Peptide)/pyrokinin-like peptides (APKYFYFPRMamide; SAFYFPRMamide); tachykinins (FGFAPMRamide, 824.01 Da; FRFTALRamide 909.09 Da), and the NdWFamide (Additional file 1). We also present for the first time the expression of opioid-like neuropeptides, considered to represent the protostome counterparts of enkephalins [2] (Additional file 1). Novel neuropeptide families displaying any obvious similarity to known peptides were named PFGx8amide, RxIamide and $\mathrm{Wx}_{3}$ Yamide according to their sequence pattern. These new families may represent mollusc or Lophotrochozoan innovations. We found no neuropeptide related to the gastropod mollusc pleurin, sensorin and enterin, however a neuropeptide PXVFamide consensus sequence corresponding exactly to the active core of the Mytilus inhibitory peptides and PXVFamide found in Aplysis and Lottia was characterized [12]. LC-MS/MS analysis of C. gigas neural tissues allowed the characterization of the majority of the predicted neuropeptides with the exception of those excluded by the mass sieve applied (600 Da $-4000 \mathrm{Da}$ ) or those harboring an intrapeptide disulfide bridge which, in absence of a reduction/alkylation step, usually do not generate interpretable mass fragments (allatostatin C, conopressin, GGNamide). Some other peptides were virtually not detected, as is the case for LASGLVamide family of neuropeptides or Luqin. We cannot rule out the possibility that the extraction procedure was not adequate or that the mature peptides are expressed at very low levels in the adult nervous system. The findings that the genes encoding these peptides (OYG_10000034, OYG_10021332) are highly expressed in pediveliger larvae highlight that there is a more specific role for these peptides during larval development (see OysterDB; http://oysterdb.cn/). The peptidomic approach confirmed the expression and the actual processing of virtually all predicted peptides. Nevertheless, some intriguing features were uncovered; these include the presence of few glycine C-terminally extended peptides together with their amidated forms (FFamide, GnRH, Mytilus inhibitory peptide [PXFVamide], Myomodulin and sCAP) as well as some extended peptides with internal processing sites (FFamide, myomodulins, pedal peptide 3, PKYMDT and NPYamide). In addition, few unpredicted peptides were also characterized (LRNFVa and NPF). Whether these peptides represent biologically active moieties or simply incomplete processed forms remain to be further investigated.

Sequence alignments of oyster neuropeptide precursors with corresponding molluscan precursors show conservation only within the putative bioactive peptides; further investigation was needed to fully comprehend their diversity and evolution in molluscs (for review, see [12]). Therefore, we used similarity-based clustering and sensitive similarity searches. Clustering recovered all known molluscan neuropeptide families (Additional file 7), several of which are unique with no connections to other families (e.g. neuropeptide precursors cerebrin, PKYMDT, bursicon alpha, elevenin, allatostatin C, sCAP/Pyrokinin, NKY, GPA2 and GnRH). However, 17 of the 42 families were strongly connected to form one large central cluster; although in the central cluster some sequences were only indirectly connected via a network of transitive BLAST connections (e.g. achatin, FFamide, luqin, CCAP and PFGx8amide). Not surprisingly, the core of the central cluster represented and contained neuropeptides with abundant repetitive peptides that give rise to short tetra to dodeca amidated (e.g. APGW, LASGL, FMRF, LFRF, mytilus inhibitory peptide, FFamide, PFGx8amide, myomodulin), and nonamidated neuropeptides (e.g., pedal peptide). This is similar to the observations made in a few recent cluster-based studies of neuropeptide families encompassing far larger datasets and not restricted to one phyla [2,31]. Several peripheral groups (e.g., ELH, conopressin, NPF/NPY and CCK/SK) were connected to the core, but not to other derived families. This adheres to the observation that these fringe neuropeptides represent independent divergences from one or more ancestral sequences within the core [2]. The protein family from opioid, Wx3Yamide, achatin-like, bursicon beta, GPB5, tachykinin, LFRYamide, NdWFamide did not mark in the map because i) their similarity to others was higher than $1 \mathrm{e}^{-5}$; and ii) they did not form a cluster in the map.

\section{Glycoproteins}

A glycoprotein family known as cysteine knot-forming heterodimers consisting of alpha- (GPA) and beta-subunits (GPB) are evolutionarily conserved [54]. In vertebrates the heterodimer is called thyrostimulin, composed of GPB5 and GPA2. Homologs occur in arthropods, nematode, cnidarians, and molluscs implying that this neurohormone system existed prior to the emergence of bilateral metazoans [55]. The GPB5 of the GPA2/GPB5 dimer was identified in P. fucata and C. gigas that is similar to the GPB5 subunits identified in Aplysia, Lottia [12] and humans [56] (Figure 6 and Additional file 1). The Pf-GPB5 and $C g$-GPB5 genes encode precursors of 137 and 133 residues, respectively, and two GPB5 peptides are predicted to be cleaved from these precursors, releasing N-terminal basic GPB5 (8193.32 Da) and a C-terminal acidic GPB5 (4708.33 Da), both of which contain five cysteine residues. GPA2 was also identified from $P$. fucata and C. gigas (Figure 6 and Additional file 1). Cg-GPA2 is encoded by a gene in tandem with $\mathrm{Cg}$ GPB5, as is the case in most species [57]. There is 


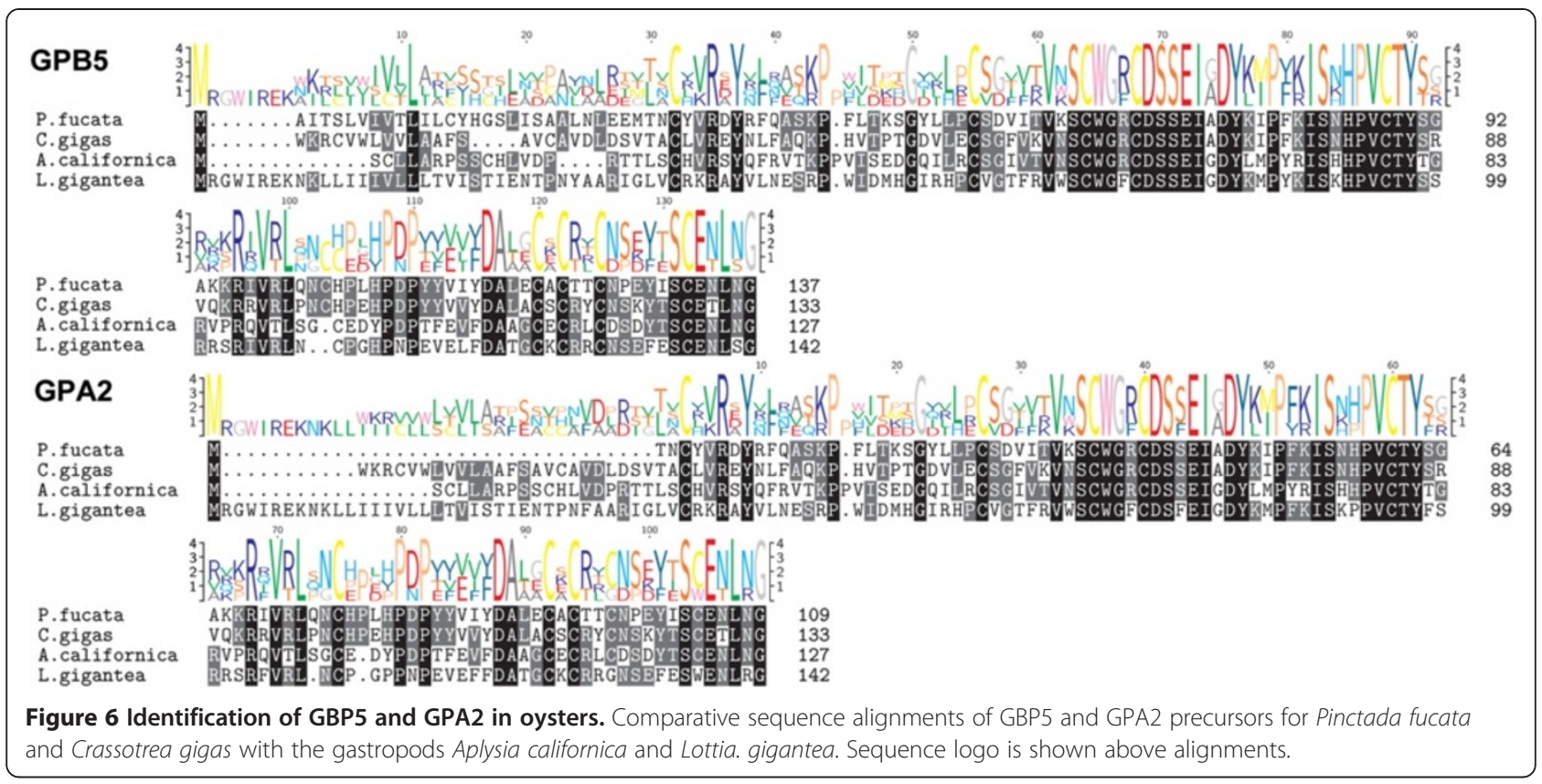

spatial conservation of cysteine residues amongst molluscan GPB5/GPA2, yet only the oysters retain the KR cleavage site. Although a function for these proteins in molluscs is currently unknown, in insects, studies using the mosquito (Aedes aegypti) suggest that GPA2/GPB5 participates in ionic and osmotic balance, since it appears to inhibit natriuresis and promote kaliuresis [55]. Bursicon, another $\alpha \beta$ heterodimer member of this cysteine knot family of neurohormones, was characterized in insects for its role in triggering the sclerotization of the cuticle and expansion of the wings during the final phase of metamorphosis [58]. Both $\alpha$ and $\beta$ bursicon-related precursors are encoded by $C$. gigas genome. Cg-Bursicon $\alpha$, a 108 amino acid long peptide, shows $53 \%$ similarity with Bombyx mori bursicon- $\beta$ subunit, though Cg-Bursicon- $\beta$ (displays $46 \%$ identity with Carcinus maenas counterpart. Cg-Bursicon- $\alpha \beta$ very likely binds oyster receptor Cg-LGRB with a possible growth/differentiation regulatory role during development and in the cytological changes occurring in the digestive gland [59].

\section{Conclusions}

In this study we described the identification of putative oyster neuropeptides using in silico genome and transcriptome database searches. The results clearly demonstrate that neuropeptide genes are conserved in bivalves, however, there are distinct differences with other molluscs. Despite a sessile mode of life and thus less intricate patterns of behavioral events, oysters have obviously retained a repertoire of neuropeptides with a complexity similar to that of other mollusc classes. The number of peptides predicted in our study supports the power of genome mining for neuropeptide gene discovery, and provides a strong foundation for future in silico investigations within oysters. Further research is additionally needed to validate peptide predictions through gene expression analysis as well as peptide expression identification using mass spectrometry approaches with other endocrine tissues and at different stages of development and metabolic states. To achieve this, target tissues would include the oysters visceral and cerebral ganglia, gonads and in depth in vivo assays of synthetic and recombinant peptides. Function must then be confirmed by bioactivity.

\section{Methods}

\section{Gene and peptide identification}

To identify target sequences, the Pinctata fucata (http:// marinegenomics.oist.jp/genomes/download?project_id=20) and Crassostrea gigas (http://gigadb.org/pacific_oyster) genome [60] and gene coding region (CDS) databases were imported into the CLC Genomics Workbench (v6.0; Finlandsgade, Dk). Previously identified molluscan neuropeptides, neurohormones and precursor processing enzyme sequences were then used to query (tBLASTn and BLASTx) the databases. In parallel, open reading frames retrieved from the databases were translated and screened for the presence of recurrent KK; KR; RK; RR motifs. In many cases, $C$. gigas gene CDS predictions could be supported from transcriptome database analyses. Multiple sequence alignments were created with the Molecular Evolutionary Genetics Analysis (MEGA) software version 5.1 [61]. Derived and actual amino acid sequences were aligned, guided by chain cleavage sites and conserved cysteines, where necessary intron donor/acceptor splice sites were identified using NetGene2 [62]. Signal 
sequences and cleavage sites were identified by alignments with other mollusc sequences $[12,63,64]$ and predicted through SignalP 4.0 [5] and NeuroPred [65]. Sequence presentation and shading of multiple sequence alignments was performed using the LaTEX TEXshade package [66].

\section{Phylogeny and neuropeptide family clustering}

Phylogenetic trees were constructed using full length precursors or individual peptides with MEGA5.1 utilising the neighbor-joining method [67]. Unrooted trees were generated with 1000 bootstrap trials and presented with a cut-off bootstrapping value of 50 . For the neuropeptide family classification, we performed a PSIBLAST with 1 iteration using all the molluscan neuropeptides identified in this study. The sequence-similarity-based clustering approaches were further applied using CLANS [68]. All the neuropeptides sequences with no similarity to other neuropeptides were removed from the final map.

\section{Precursor schematics and peptide modelling}

Schematic diagrams of protein domain structures were prepared using the Domain Graph (DOG, version 2.0) software [69]. Protein secondary structure predictions were made using PredictProtein (http://www.predictprotein.org/), and protein 3D models were built using the Assisted Model Building with Energy Refinement (AMBER) 11 [70] with a modified procedure described elsewhere [71], in which the structures of molecular dynamic simulation were sampled every picosecond for a total of 350 nanoseconds, and a representative structure (i.e. the lowest energy structure) was obtained once the RMSD during a long time period was below $\sim 2 \AA$. To characterize the secondary structure of $P$. fucata ELH, CD analysis was performed using a $0.1 \mathrm{~cm}$ path length cell at $0.2 \mathrm{~nm}$ intervals with two scans $\left(178-260 \mathrm{~nm}\right.$ ) averaged for each at $25^{\circ} \mathrm{C}$ (Jasco J-715 spectropolarimeter, JASCO, Easton, MD, USA). Lyophilized ELH was slowly dissolved in $10 \mathrm{mM}$ sodium phosphate buffer $(\mathrm{pH} 6.5)$, centrifuged at $15,000 \times \mathrm{g}$ to remove precipitated protein. It was then concentrated to a volume of $0.5 \mathrm{ml}$ by centrifugation at $7000 \times \mathrm{g}$ in a Centricon 3 concentrator (Amicon, Beverly, MA, USA). One more addition of buffer and concentration was performed, after which the protein was diluted with additional sodium phosphate buffer to a final concentration of $0.3 \mathrm{mg} / \mathrm{ml}$. Far-UV CD spectra were taken at a protein concentration of $0.1 \mathrm{mg} / \mathrm{L}$ and the resultant spectra corrected for the buffer signal. The CD spectrum of $P$ fucata ELH was interpreted with the program, Contin using the DICHROWEB site [72-74].

\section{Animals and extraction of peptides from visceral ganglia and nano-LC purification}

All experiments were conducted in accordance within Australian laws, and laws imparted by French counterparts, and thus required no ethics approval for the animals used in the study.

Two-year old adult C. gigas purchased from an oyster farm (Normandie, France) were used for peptide identification. Twenty animal equivalents of visceral ganglia were extracted in $0.1 \%$ trifluoroacetic acid (TFA) at $4^{\circ} \mathrm{C}$ and centrifuged for $30 \mathrm{~min}$ at $35,000 \times \mathrm{g}$ at $4^{\circ} \mathrm{C}$. The supernatants were concentrated on Chromafix $\mathrm{C}_{18}$ solid phase extraction cartridges (Macherey-Nagel). Samples were evaporated and nano-LC purification performed as described in Bigot et al. [38].

\section{Mass spectrometry analysis}

MS analysis were carried out on an AB Sciex 5800 proteomics analyzer equipped with TOF-TOF ion optics and an OptiBeamTM on-axis laser irradiation with $1000 \mathrm{~Hz}$ repetition rate. The system was calibrated immediately before analysis with a mixture of desArg-Bradykinin, Angiotensin I, Glu1-Fibrinopeptide B, ACTH (18-39), ACTH (7-38) and mass precision was above $50 \mathrm{ppm}$. A $0.8 \mu \mathrm{l}$ volume of the HPLC fraction was mixed with $1.6 \mu \mathrm{l}$ volume of a suspension of CHCA matrix prepared in 50\% ACN/0.1\% TFA solvent. The mixture was spotted on a stainless steel OptiTOFTM 384 targets; the droplet was allowed to evaporate before introducing the target into the mass spectrometer. All acquisitions were taken in automatic mode. A laser intensity of 3000 was typically employed for ionizing. MS spectra were acquired in the positive reflector mode by summarizing 1000 single spectra $(5 \times 200)$ in the mass range from 600 to $4000 \mathrm{Da}$. MS/ MS spectra were acquired in the positive MS/MS reflector mode by summarizing a maximum of 2500 single spectra $(10 \times 250)$ with a laser intensity of 3900 . For the tandem MS experiments, the acceleration voltage applied was $1 \mathrm{kV}$ and air was used as the collision gas. Gas pressure medium was selected as settings. The fragmentation pattern was used to determine the sequence of the peptide. Database searching was performed using the Mascot 2.3.02 program (Matrix Science) from the latest version of C. gigas transcriptome "GigasDatabase" [60] (including 1,013,570 entries) http://publiccontigbrowser. sigenae.org:9090/Crassostreagigas/index.html and C. gigas genome sequence database http://oysterdb.cn/. The variable modifications allowed were as follows: C-terminal amidation, N-terminal pyroglutamate, N-terminal acetylation, methionine oxidation and dioxidation. Mass accuracy was set to $300 \mathrm{ppm}$ and 0.6 Da for MS and MS/MS mode respectively. Mascot data were then transferred to an in-house developed validation software for data filtering according to a significance threshold of Mascot score $>20$ and the elimination of protein redundancy on the basis of proteins being evidenced by the same set or a subset of peptides. Each peptide sequence was checked manually to 
confirm or contradict the Mascot assignment. Sequences corresponding to irrelevant identifications were discarded.

\section{Additional files}

\section{Additional file 1: Genes encoding putative full-length or partial- length neuropeptide precursors from the Pinctada fucata and Crassostrea gigas genome, and transcriptome databases for C. gigas.}

Additional file 2: Summary of neuropeptide precursors and cleaved products predicted from Pinctata fucata and Crassostrea gigas. Blue colored peptides indicate those identified from visceral ganglia by mass spectrometry. Database Accession numbers for sequences used in this study.

Additional file 3: Off-line nLC-MALDI tandem MS analysis of $C$. gigas cerebral ganglia. MS/MS spectrum of the neuropeptides $\mathrm{Cg}$ buccalin: GLDRYSFYGGLa m/z 1246.6, Cg-cerebrin; NLGTVDSLYNLPDLLYRa m/z 1965, Cg-FFamide: GMNPNMNSLFFa m/z 1270.6. Immonium, a-, b- and $y$-ions detected are marked.

Additional file 4: List of peptides molecularly characterized by nLC-MALDI tandem MS analysis of oyster cerebral ganglia Peptide sequence was validated according to a significance threshold of Mascot probability based score $>\mathbf{2 0}$ and checked manually to confirm or contradict the Mascot assignment. Na.a and Ca.a: flanking amino and carboxy amino acids on the precursor.

Additional file 5: Complete list of neuropeptides in a FASTA format.

Additional file 6: Potential energy of Pinctada fucata and Crassostrea gigas ELH1 and ELH2 as a function of time during MD (Figures 1-4). Figure 5 shows the results of analysis of the secondary structure of Pf-ELH1 based on CD spectroscopy.

Additional file 7: PSI-BLAST cluster map of all the molluscan neuropeptides used in this study. Nodes are colored based on protein family. Edges represent the BLAST connections of $P$ value $<1 e^{-5}$. The identifier of oyster neuropeptides is provided in Figure 1, and all molluscan neuropeptides in Additional file 2.

\section{Abbreviations}

LC: Liquid chromatography; MALDI-TOF: Matrix-assisted laser desorption/ ionization time-of-flight; MS: Mass spectrometry; RMSD: Root-mean square distance; ELH: Egg-laying hormone; FCAP: Feed circuit activating peptide; GnRH: Gonadotropin-releasing hormone; GPBA: Glycoprotein alpha; GPB5: Glycoprotein beta; NPF: Neuropeptide F; NKY: Neuropeptide KY; NPY: Neuropeptide Y; CCK: Cholecystokinin; SK-like: Sulfakinin.

\section{Competing interests}

The authors declare that they have no competing interests.

\section{Authors' contributions}

MJS carried out the genome analysis of $P$. fucata, C. gigas and other molluscs, constructed figures, tables and drafted the manuscript. PF and JH carried out proteome work and obtained funding to construct EST libraries for C. gigas where needed. BAR assembled DOG schematics, and undertook the phylogenetic analysis. TW constructed and analysed ELH protein models. MS performed circular dichromism of ELH. MZ performed the bioinformatics PSI-BLAST analysis. WO, AE, and SFC conceived the idea and obtained funding for the experiments and drafted the manuscript. All authors read and approved the final manuscript.

\section{Acknowledgements}

This work was supported by grants from the Australian Research Council (SFC), the University of the Sunshine Coast (AE, SFC), ANR (ANR-08-GENM041) (PF) and EU FP7-KBBE-2009 (REPROSEED grant no. 245119) (PF, JH). Mass spectrometry analysis was performed at the technical platform "Proteogen" of SF ICORE 4206 of the University of Caen Basse-Normandie (Dr. B. Bernay). This research was undertaken with the assistance of resources provided at the NCl National Facility systems at the Australian National University through the National Computational Merit Allocation Scheme supported by the Australian Government.

\section{Author details}

'School of Science and Education, Genecology Research Center, University of the Sunshine Coast, Maroochydore DC, Queensland 4558, Australia. ${ }^{2}$ Université de Caen Basse-Normandie, Biologie des ORganismes et Ecosystèmes Aquatiques (BOREA), Caen 14032, France. ${ }^{3}$ CNRS UMR 7208, BOREA, Caen, France. ${ }^{4}$ Port Stephens Fisheries Institute, Locked Bag 1, Nelson Bay, New South Wales 2315, Australia.

Received: 19 May 2014 Accepted: 3 September 2014 Published: 2 October 2014

\section{References}

1. Burbach JPH: What are neuropeptides? In Neuropeptides: Methods and protocols. Edited by Merighi A. New York: Humana Press; 2011:1-36.

2. Jekely G: Global view of the evolution and diversity of metazoan neuropeptide signaling. Proc Natl Acad Sci U S A 2013, 110(21):8702-8707

3. Kim YJ, Zitnan D, Galizia CG, Cho KH, Adams ME: A command chemical triggers an innate behavior by sequential activation of multiple peptidergic ensembles. Curr Biol 2006, 16(14):1395-1407.

4. Hartenstein V: The neuroendocrine system of invertebrates: a developmental and evolutionary perspective. J Endocrinol 2006, 190(3):555-570.

5. Bendtsen JD, Nielsen $H$, von Heijne G, Brunak S: Improved prediction of signal peptides: SignalP 3.0. J Mol Biol 2004, 340(4):783-795.

6. Tager HS, Steiner DF: Peptide hormones. Annu Rev Biochem 1974 43:509-538.

7. Hokfelt T, Broberger C, Xu ZQ, Sergeyev V, Ubink R, Diez M: Neuropeptides-an overview. Neuropharmacology 2000, 39(8):1337-1356.

8. Hook V, Funkelstein L, Lu D, Bark S, Wegrzyn J, Hwang SR: Proteases for processing proneuropeptides into peptide neurotransmitters and hormones. Annu Rev Pharmacol Toxicol 2008, 48:393-423.

9. Eipper BA, Stoffers DA, Mains RE: The biosynthesis of neuropeptides: peptide alpha-amidation. Annu Rev Neurosci 1992, 15:57-85.

10. Mirabeau O, Joly JS: Molecular evolution of peptidergic signaling systems in bilaterians. Proc Natl Acad Sci U S A 2013, 110(22):E2028-2037.

11. Feldmesser E, Rosenwasser S, Vardi A, Ben-Dor S: Improving transcriptome construction in non-model organisms: integrating manual and automated gene definition in Emiliania huxleyi. BMC Genomics 2014, 15:148.

12. Veenstra JA: Neurohormones and neuropeptides encoded by the genome of Lottia gigantea, with reference to other mollusks and insects. Gen Comp Endocrinol 2010, 167(1):86-103.

13. Takeuchi T, Kawashima T, Koyanagi R, Gyoja F, Tanaka M, Ikuta T, Shoguchi E, Fujiwara M, Shinzato C, Hisata K, Fujie M, Usami T, Nagai K, Maeyama K, Okamoto K, Aoki H, Ishikawa T, Masaoka T, Fujiwara A, Endo K, Endo H, Nagasawa H, Kinoshita S, Asakawa S, Watabe S, Satoh N: Draft genome of the pearl oyster Pinctada fucata: a platform for understanding bivalve biology. DNA Res 2012, 19(2):117-130

14. Zhang G, Fang X, Guo X, Li L, Luo R, Xu F, Yang P, Zhang L, Wang X, Qi H, Xiong Z, Que H, Xie Y, Holland PW, Paps J, Zhu Y, Wu F, Chen Y, Wang J, Peng C, Meng J, Yang L, Liu J, Wen B, Zhang N, Huang Z, Zhu Q, Feng Y, Mount A, Hedgecock D, et al: The oyster genome reveals stress adaptation and complexity of shell formation. Nature 2012, 490(7418):49-54.

15. Pit JH: Feasibility of Akoya pearl oyster culture in Queensland. James Cook Universit: Townsvilley; 2004

16. Matsumoto T, Masaoka T, Fujiwara A, Nakamura Y, Satoh N, Awaji M: Reproduction-related genes in the pearl oyster genome. Zoological Science 2013, 30(10):826-850.

17. Fan X, Croll RP, Wu B, Fang L, Shen Q, Painter SD, Nagle GT: Molecular cloning of a cDNA encoding the neuropeptides APGWamide and cerebral peptide 1: localization of APGWamide-like immunoreactivity in the central nervous system and male reproductive organs of Aplysia. J Comp Neurol 1997, 387(1):53-62.

18. Smit AB, Jimenez CR, Dirks RW, Croll RP, Geraerts WP: Characterization of a cDNA clone encoding multiple copies of the neuropeptide APGWamide in the mollusk Lymnaea stagnalis. J Neurosci 1992, 12(5):1709-1715. 
19. Koene JM: Neuro-endocrine control of reproduction in hermaphroditic freshwater snails: mechanisms and evolution. Front Behav Neurosci 2010, 4:167.

20. Henry J, Zatylny C: Identification and tissue mapping of APGWamiderelated peptides in Sepia officinalis using LC-ESI-MS/MS. Peptides 2002, 23(6):1031-1037.

21. Henry J, Favrel P, Boucaud-Camou E: Isolation and identification of a novel Ala-Pro-Gly-Trp-amide-related peptide inhibiting the motility of the mature oviduct in the cuttlefish Sepia officinalis. Peptides 1997, 18(10):1469-1474.

22. Favrel $P$, Mathieu M: Molecular cloning of a cDNA encoding the precursor of Ala-Pro-Gly-Trp amide-related neuropeptides from the bivalve mollusc Mytilus edulis. Neurosci Lett 1996, 205(3):210-214.

23. Henry J, Zatylny C, Favrel P: HPLC and electrospray ionization mass spectrometry as tools for the identification of APGWamide-related peptides in gastropod and bivalve mollusks: comparative activities on Mytilus muscles. Brain Res 2000, 862(1-2):162-170.

24. Cropper EC, Brezina V, Vilim FS, Harish O, Price DA, Rosen S, Kupfermann I, Weiss KR: FRF peptides in the ARC neuromuscular system of Aplysia: purification and physiological actions. J Neurophysiol 1994 72(5):2181-2195

25. Hoek RM, Li KW, van Minnen J, Lodder JC, de Jong-Brink M, Smit AB, van Kesteren RE: LFRFamides: a novel family of parasitation-induced -RFamide neuropeptides that inhibit the activity of neuroendocrine cells in Lymnaea stagnalis. J Neurochem 2005, 92(5):1073-1080.

26. Walker RJ, Papaioannou S, Holden-Dye L: A review of FMRFamide- and RFamide-like peptides in metazoa. Invert Neurosci 2009, 9(3-4):111-153.

27. Moulis A: The action of RFamide neuropeptides on molluscs, with special reference to the gastropods Buccinum undatum and Busycon canaliculatum. Peptides 2006, 27(5):1153-1165.

28. Fujino $Y$, Nagahama T, Oumi T, Ukena K, Morishita F, Furukawa $Y$, Matsushima O, Ando M, Takahama H, Satake H, Minakata H, Nomoto K Possible functions of oxytocin/vasopressin-superfamily peptides in annelids with special reference to reproduction and osmoregulation. J Exp Zool 1999, 284(4):401-406.

29. Gajewski M, Leitz T, Schloßherr J, Plickert G: LWamides from Cnidaria constitute a novel family of neuropeptides with morphogenetic activity. Rouxs Arch Dev Biol 1996, 205:232-242.

30. Matsushima O, Takahashi T, Morishita F, Fujimoto M, Ikeda T, Kubota I, Nose T, Miki W: Two S-lamide peptides, AKSGFVRlamide and VSSFVRlamide, isolated from an annelid, Perinereis vancaurica. Biol Bull 2002, 184:216-222.

31. Conzelmann M, Williams EA, Krug K, Franz-Wachtel M, Macek B, Jekely G The neuropeptide complement of the marine annelid Platynereis dumerilii. BMC Genomics 2013, 14:906

32. Kuroki $Y$, Kanda T, Kubota I, Ikeda T, Fujisawa Y, Minakata H, Muneoka Y: FMRFamide-related peptides isolated from the prosobranch mollusc Fusinus ferrugineus. Acta Biol Hung 1993, 44(1):41-44.

33. Galtsoff PS: Physiology of reproduction of Ostrea virginica. II. Stimulation of Spawning in the Female Oyster. Biol Bull 1938, 75(2):286-307.

34. Roch GJ, Busby ER, Sherwood NM: Evolution of GnRH: diving deeper Gen Comp Endocrinol 2011, 171(1):1-16.

35. Iwakoshi E, Takuwa-Kuroda K, Fujisawa Y, Hisada M, Ukena K, Tsutsui K, Minakata $\mathrm{H}$ : Isolation and characterization of a $\mathrm{GnRH}$-like peptide from Octopus vulgaris. Biochem Biophys Res Commun 2002, 291(5):1187-1193.

36. Zhang L, Tello JA, Zhang W, Tsai PS: Molecular cloning, expression pattern, and immunocytochemical localization of a gonadotropinreleasing hormone-like molecule in the gastropod mollusk. Aplysia californica. Gen Comp Endocrinol 2008, 156(2):201-209.

37. Nakamura S, Osada M, Kijima A: Involvement of GnRH neuron in the spermatogonial proliferation of the scallop. Patinopecten yessoensiss. Mol Reprod Dev 2007, 74(1):108-115.

38. Bigot L, Zatylny-Gaudin C, Rodet F, Bernay B, Boudry P, Favrel P: Characterization of GnRH-related peptides from the Pacific oyster Crassostrea gigas. Peptides 2012, 34(2):303-310.

39. Strumwasser F, Schiller DL, Kent SBH: Synthetic neuropeptide egg- laying hormone (ELH) of Aplysia californica induces normal egg-laying: structure-activity studies. Soc Neurosci Abstr 1987, 13:38.

40. Cummins SF, York PS, Hanna PH, Degnan BM, Croll RP: Expression of prohormone convertase 2 and the generation of neuropeptides in the developing nervous system of the gastropod Haliotis. Int J Dev Biol 2009, 53(7):1081-1088.
41. Cummins SF, Nuurai P, Nagle GT, Degnan BM: Conservation of the egg-laying hormone neuropeptide and attractin pheromone in the spotted sea hare, Aplysia dactylomela. Peptides 2010, 31(3):394-401.

42. Kamatani Y, Minakata H, Kenny PT, Iwashita T, Watanabe K, Funase K, Sun XP, Yongsiri A, Kim KH, Novales-Li P, Novales ET, Kanapi CG, Takeuchi H, Nomoto K: Achatin-I, an endogenous neuroexcitatory tetrapeptide from Achatina fulica Ferussac containing a D-amino acid residue. Biochem Biophys Res Commun 1989, 160(3):1015-1020.

43. Liu GJ, Takeuchi H: Modulation of neuropeptide effects by achatin-I, an Achatina endogenous tetrapeptide. Eur J Pharmacol 1993, 240(2-3):139-145.

44. Kataoka H, Toschi A, Li JP, Carney RL, Schooley DA, Kramer SJ: Identification of an allatotropin from adult Manduca sexta. Science 1989, 243 (4897):1481-1483.

45. Schoofs L, Jensson T, Nachman RJ: Sulfakinins. In Handbook of Biological Active Peptides, Volume 2. Edited by Kastin AJ. San Diego: Elsevier Press; 2013:310-314

46. Elphick MR: NG peptides: A novel family of neurophysin-associated neuropeptides. Gene 2010, 458:20-26.

47. Van Kesteren RE, Smit AB, De Lange RP, Kits KS, Van Golen FA, Van Der Schors RC, De With ND, Burke JF, Geraerts WP: Structural and functional evolution of the vasopressin/oxytocin superfamily: vasopressin-related conopressin is the only member present in Lymnaea, and is involved in the control of sexual behavior. J Neurosci 1995, 15(9):5989-5998.

48. Taussig R, Kaldany RR, Rothbard JB, Schoolnik G, Scheller RH: Expression of the L11 neuropeptide gene in the Aplysia central nervous system. J Comp Neurol 1985, 238(1):53-64

49. Veenstra JA: Neuropeptide evolution: neurohormones and neuropeptides predicted from the genomes of Capitella teleta and Helobdella robusta. Gen Comp Endocrinol 2011, 171(2):160-175.

50. Nassel DR, Wegener C: A comparative review of short and long neuropeptide F signaling in invertebrates: Any similarities to vertebrate neuropeptide $Y$ signaling? Peptides 2011, 32(6):1335-1355.

51. Zatylny-Gaudin C, Bernay B, Zanuttini B, Leprince J, Vaudry H, Henry J: Characterization of a novel LFRFamide neuropeptide in the cephalopod Sepia officinalis. Peptides 2010, 31(2):207-214.

52. Bigot L, Beets I, Dubos MP, Boudry P, Schoofs L, Favrel P: Functional characterization of a short neuropeptide F-related receptor in a Lophotrochozoa, the mollusk Crassostrea gigas. J Exp Biol 2014, 217:2974-2982.

53. Li KW, el Filali Z, Van Golen FA, Geraerts WP: Identification of a novel amide peptide, GLTPNMNSLFF-NH2, involved in the control of vas deferens motility in lymnaea stagnalis. Eur J Biochem 1995, 229(1):70-72

54. Sellami A, Agricola HJ, Veenstra JA: Neuroendocrine cells in Drosophila melanogaster producing GPA2/GPB5, a hormone with homology to LH FSH and TSH. Gen Comp Endocrinol 2011, 170(3):582-588.

55. Paluzzi J-P, Vanderveken M, O'Donnell MJ: The heterodimeric glycoprotein hormone, GPA2/GPB5, regulates ion transport across the hindgut of the adult mosquito, Aedes aegypti. PLoS One 2014. doi:10.1371/journal.pone.0086386.

56. Nakabayashi K, Matsumi H, Bhalla A, Bae J, Mosselman S, Hsu SY, Hsueh A.: Thyrostimulin, a heterodimer of two new human glycoprotein hormone subunits, activates the thyroid-stimulating hormone receptor. J Clin Invest 2002, 109(11):1445-1452.

57. Dos Santos S, Bardet C, Bertrand S, Escriva H, Habert D, Querat B: Distinct expression patterns of glycoprotein hormone-alpha2 and -beta5 in a basal chordate suggest independent developmental functions. Endocrinology 2009, 150(8):3815-3822.

58. Mendive FM, Van Loy T, Claeysen S, Poels J, Williamson M, Hauser F, Grimmelikhuijzen CJ, Vassart G, Vanden Broeck J: Drosophila molting neurohormone bursicon is a heterodimer and the natural agonist of the orphan receptor DLGR2. FEBS Lett 2005, 579(10):2171-2176.

59. Herpin A, Badariotti F, Rodet F, Favrel P: Molecular characterization of a new leucine-rich repeat-containing $G$ protein-coupled receptor from a bivalve mollusc: evolutionary implications. Biochim Biophys Acta 2004, 1680(3):137-144.

60. Fleury E, Huvet A, Lelong C, de Lorgeril J, Boulo V, Gueguen Y, Bachere E, Tanguy A, Moraga D, Fabioux C, Lindeque $\mathrm{P}$, Shaw J, Reinhardt R, Prunet $\mathrm{P}$, Davey G, Lapègue S, Sauvage C, Corporeau C, Moal J, Gavory F, Wincker P, Moreews F, Klopp C, Mathieu M, Boudry P, Favrel P: Generation and analysis of a 29,745 unique Expressed Sequence Tags from the Pacific oyster (Crassostrea gigas) assembled into a publicly accessible database: the GigasDatabase. BMC Genomics 2009, 10:341. 
61. Kumar S, Stecher G, Peterson D, Tamura K: MEGA-CC: computing core of molecular evolutionary genetics analysis program for automated and iterative data analysis. Bioinformatics 2012, 28(20):2685-2686.

62. Brunak S, Engelbrecht J, Knudsen S: Prediction of human mRNA donor and acceptor sites from the DNA sequence. J Mol Biol 1991, 220(1):49-65.

63. Floyd PD, Li L, Moroz TP, Sweedler JV: Characterization of peptides from Aplysia using microbore liquid chromatography with matrix-assisted laser desorption/ionization time-of-flight mass spectrometry guided purification. J Chromatogr A 1999, 830(1):105-113.

64. Hamano K, Awaji M, Usuki H: cDNA structure of an insulin-related peptide in the Pacific oyster and seasonal changes in the gene expression. J Endocrinol 2005, 187(1):55-67.

65. Southey BR, Amare A, Zimmerman TA, Rodriguez-Zas SL, Sweedler JV: NeuroPred: a tool to predict cleavage sites in neuropeptide precursors and provide the masses of the resulting peptides. Nucleic Acids Res 2006, 34(Web Server issue):W267-272.

66. Beitz E: TEXshade: shading and labeling of multiple sequence alignments using LATEX2 epsilon. Bioinformatics 2000, 16(2):135-139.

67. Saitou N, Nei M: The neighbor-joining method: a new method for reconstructing phylogenetic trees. Mol Biol Evol 1987, 4(4):406-425.

68. Frickey T, Lupas A: CLANS: a Java application for visualizing protein families based on pairwise similarity. Bioinformatics 2004, 20(18):3702-3704.

69. Ren J, Wen L, Gao X, Jin C, Xue Y, Yao X: DOG 1.0: illustrator of protein domain structures. Cell Res 2009, 19(2):271-273.

70. Case DA, Darden TA, Cheatham ITE, Simmerling CL, Wang J, Duke RE, Luo R, Walker RC, Zhang W, Merz KM, Paesani F, Roe DR, Roitberg A, Sagui C, Salomon-Ferrer R, Seabra G, Simmerling CL, Smith W, Swails J, Walker RC, Wang J, Wolf RM, Wu X, Kollman PA: AMBER 11. San Francisco: University of California; 2010.

71. Simmerling C, Strockbine B, Roitberg AE: All-atom structure prediction and folding simulations of a stable protein. J Am Chem Soc 2002, 124:11258-11259.

72. Whitmore L, Woollett B, Miles AJ, Janes RW, Wallace BA: The protein circular dichroism data bank, a Web-based site for access to circular dichroism spectroscopic data. Structure 2010, 18(10):1267-1269.

73. Whitmore L, Wallace BA: DICHROWEB, an online server for protein secondary structure analyses from circular dichroism spectroscopic data. Nucleic Acids Res 2004, 32(Web Server issue):W668-673.

74. Lobley A, Whitmore L, Wallace BA: DICHROWEB: an interactive website for the analysis of protein secondary structure from circular dichroism spectra. Bioinformatics 2002, 18(1):211-212.

doi:10.1186/1471-2164-15-840

Cite this article as: Stewart et al:: Neuropeptides encoded by the genomes of the Akoya pearl oyster Pinctata fucata and Pacific oyster Crassostrea gigas: a bioinformatic and peptidomic survey. BMC Genomics 2014 15:840.

\section{Submit your next manuscript to BioMed Central and take full advantage of:}

- Convenient online submission

- Thorough peer review

- No space constraints or color figure charges

- Immediate publication on acceptance

- Inclusion in PubMed, CAS, Scopus and Google Scholar

- Research which is freely available for redistribution 